\title{
Bronchopneumonia in sheep associated with Providencia stuartii
}

\author{
Broncopneumonia em ovinos associada a Providencia stuartii
}

Bronconeumonía en ovinos asociada a Providencia stuartii

Recebido: 14/11/2021 | Revisado: 22/11/2021 | Aceito: 26/11/2021 | Publicado: 08/12/2021

Francielle Cristina Kagueyama

ORCID: https://orcid.org/0000-0002-9760-3400

Federal University of Mato Grosso, Brazil

E-mail: franciellekagueyama@ hotmail.com

Fernanda Harumi Maruyama

ORCID: https://orcid.org/0000-0002-1847-7574

Federal University of Mato Grosso, Brazil E-mail: fer_19_nanda@hotmail.com

Edson Moleta Colodel

ORCID: https://orcid.org/0000-0002-7866-3125

Federal University of Mato Grosso, Brazil

E-mail: moleta@gmail.com

Lucas Avelino Dandolini Pavelegini

ORCID: https://orcid.org/0000-0001-9241-6641

Federal University of Mato Grosso, Brazil

E-mail: lucasavelinodandolini@gmail.com

Luciano Nakazato

ORCID: https://orcid.org/0000-0002-1244-0690

Federal University of Mato Grosso, Brazil E-mail: lucnaka@gmail.com

Valéria Dutra

ORCID: https://orcid.org/0000-0002-6630-2293

Federal University of Mato Grosso, Brazil

E-mail: valeriadutra.dutra@gmail.com

\begin{abstract}
Bacteria of the genus Providencia are opportunistic pathogens in humans, widely distributed in the environment and associated with greater resistance to antibiotics, and this being uncommon the association with clinical diseases. This study reports the isolation of $P$. stuartii in two sheep that presented clinical signs of pneumonia. At necropsy there was severe and acute fibrinopurulent bronchopneumonia. Histologically, there were infiltrated neutrophils and fibrin in the alveolar lumen, and the alveolar septa presented multifocal thickening with moderate proliferation of pneumocytes and mononuclear interstitial infiltrate. Providencia sp. was isolated in the microbiological tests of the lung and tracheal secretions. The isolate was subjected to DNA extraction, polymerase chain reaction (PCR) for the 16SrRNA gene and sequencing of genomic DNA, which demonstrated 100\% homology with P. stuartii. This is the first report of the presence of this microorganism as a cause of interstitial and fibrinopurulent bronchopneumonia in sheep. Therefore, it is suggested that epidemiological surveillance strategies should be carried out in animals to better understand their role in the dissemination of this pathogen.
\end{abstract}

Keywords: Microbiology; Pathology; Pneumonia; Sequencing; Sheep.

\section{Resumo}

Bactérias do gênero Providencia são patógenos oportunistas em humanos, amplamente distribuídas no ambiente e estão associadas a maior resistência aos antibióticos, sendo incomum a associação com doenças clinicas. Este estudo relata o isolamento de P. stuartii em duas ovelhas que apresentaram sinais clínicos de pneumonia. Na necropsia havia broncopneumonia fibrinopurulenta aguda e grave. Histologicamente, havia neutrófilos infiltrados e fibrina na luz alveolar, e os septos alveolares apresentavam espessamento multifocal com proliferação moderada de pneumócitos e infiltrado intersticial mononuclear. Providencia sp. foi isolado nos exames microbiológicos do pulmão e secreções traqueais. O isolado foi submetido à extração de DNA, reação em cadeia da polimerase (PCR) para o gene 16SrRNA e sequenciamento do DNA genômico, que demonstrou $100 \%$ de homologia com P. stuartii. Este é o primeiro relato da presença desse microrganismo como causa de broncopneumonia intersticial e fibrinopurulenta em ovinos. Portanto, sugere-se que estratégias de vigilância epidemiológica devam ser realizadas em animais para melhor compreensão de seu papel na disseminação desse patógeno.

Palavras-chave: Microbiologia; Patologia; Pneumonia; Sequenciamento; Ovinos. 


\section{Resumen}

Las bacterias del género providencia son patógenos oportunistas en el ser humano, ampliamente distribuidos en el medio ambiente y asociados a una mayor resistencia a los antibióticos, siendo infrecuente la asociación con enfermedades clínicas. Este estudio reporta el aislamiento de $P$. stuartii en dos ovejas que presentaban signos clínicos de neumonía. En la necropsia había bronconeumonía fibrinopurulenta aguda y grave. Histológicamente había neutrófilos infiltrados y fibrina en la luz alveolar, y los septos alveolares presentaban engrosamiento multifocal con moderada proliferación de neumocitos e infiltrado intersticial mononuclear. Providencia sp. se aisló en las pruebas microbiológicas de las secreciones pulmonares y traqueales. El aislado se sometió a extracción de ADN, reacción en cadena de la polimerasa (PCR) para el gen 16SrRNA y secuenciación del ADN genómico, que demostró una homología del $100 \%$ con $P$. stuartii. Este es el primer reporte de la presencia de este microorganismo como causa de bronconeumonía intersticial y fibrinopurulenta en ovinos. Por tanto, se sugiere que se lleven a cabo estrategias de vigilancia epidemiológica en animales para comprender mejor su papel en la diseminación de este patógeno.

Palabras clave: Microbiología; Patología; Neumonía; Secuenciación; Ovino.

\section{Introduction}

The genus Providencia comprises gram-negative rods that include ten species: $P$. alcalifaciens, $P$. heimbachae, $P$. rettgeri, P. rustigianii, P. stuartii, P. vermicola, P. sneebia, P. burhodogranariea, P. thailandensis (Juneja \& Lazzaro, 2009; Muller et al., 1986; Somvanshi et al., 2006) and the new species P. entomophila (Ksentini et al., 2019). Unlike other members of the Enterobacteriaceae family, they are characterized by the ability to oxidatively deaminate to the corresponding keto acid and ammonia (Farmer et al., 1985).

Widely distributed in the environment, species of Providencia are important opportunistic pathogens in humans, being associated with higher antibiotic resistance (Wie, 2015). Research related to resistance genes and their environmental dissemination show their importance in public health (Iwata et al., 2020), mainly due to the growth of intrisic resistance to antibiotics that are considered last-resort treatments and the gene acquisition that code for different enzymes (Liu et al., 2020; Tavares et al., 2015). Providencia stuartii is present in the environment, including water and soil, and is also responsible for nosocomial infections (Liakopoulos et al., 2017). In humans, this bacterium has been isolated mainly from patients with chronic urinary tract diseases who are subjected to prolonged use of catheters (Barl et al., 2012; Wie, 2015). However, reports of the presence of renal and hepatic abscesses (Chamberland et al., 2013; Lin et al., 2017), meningitis (Sipahi et al., 2010), endocarditis (Krake \& Tandon, 2004), conjunctivitis (Crane et al., 2016) and septic vasculitis (George et al, 2020) have also been described in the literature.

Descriptions in animals are scarce in the literature, being associated with primate sepsis, ulcerative dermatitis and cellulitis in canine and diarrheal swine feces (Almeida et al., 2007; Liu et al., 2016; Papadogiannakis et al., 2007). In addition, Providencia spp. were found in retail meats in China and Japan (Di et al., 2018) and Barbour et al (2012) isolated of liver from broiler chicken in Lebanon, which could cause a serious public health problem

Therefore, this report describes the pathological findings, microbiological and molecular analyses of $P$. stuartii present in the lung of sheep with bronchopneumonia, highlighting that animals may be important sources of transmission to humans, in addition to enabling the spread of Providencia spp. in food.

\section{Methodology}

A batch of 150 sheep was purchased and introduced to a property in the municipality of Santo Antônio de Leverger MT. Within 3 months, some animals showed clinical signs of difficulty breathing and coughing. Of these, two young male sheep, weighing $15 \mathrm{~kg}$ and $17.3 \mathrm{~kg}$, presented slightly pale oral and ocular mucosa, evolving to death.

A fragment of the lung and a sample of the tracheal secretion were sent for bacteriological isolation to the Laboratory of Microbiology (HOVET-UFMT), seeded in 8\% Sheep Blood Agar, MacConkey Agar and Sabourad Agar, incubated in 
aerobic conditions at $37^{\circ} \mathrm{C}$ for up to 7 days, and after growth, colony identification was performed according to Quinn et al. (2011).

For molecular characterization, the isolate was inoculated in Brain Heart Infusion Broth (BHI) and incubated at $37^{\circ} \mathrm{C}$ overnight. After centrifugation, the precipitate was resuspended in $1 \mathrm{~mL}$ lysis buffer $(100 \mathrm{mM} \mathrm{NaCl}, 25 \mathrm{mM}$ EDTA, $100 \mathrm{mM}$ Tris- $\mathrm{HCl} \mathrm{pH}$ 8.0, 0.5\% SDS, 0.1mg Proteinase K) and DNA was extracted using the phenol-chloroform method, according to Sambrook and Russell (2004). The DNA was resuspended with $50 \mu$ of ultrapure water. To verify the integrity and quality of the extract, the DNA was stained with Gel Red (Biotium), subjected to $1.5 \%$ agarose gel electrophoresis at $100 \mathrm{~V}$ for $40 \mathrm{~min}$, and visualized on ChemiDocTM XRS using ImageLabTM® software.

PCR was performed to sequence the $16 \mathrm{~S}$ rRNA, using the oligonucleotide pairs 27F: AGA GTT TGA TCC TGG CTC AG (Lane, 1991) and 1492R: GGT TAC CTT GTT ACG ACT T (Turner et al., 1999), amplifying products of 1424 bp. The reaction was performed with $10 \mathrm{ng}$ genomic DNA, 0.4 pmol oligonucleotides, $0.2 \mathrm{mM} \mathrm{dNTPs,} 3 \mathrm{mM} \mathrm{MgCl}_{2}, 1 \mathrm{x}$ PCR buffer 10x (200 mM Tris-HCL pH 8.4 and $500 \mathrm{mM} \mathrm{KCl),} 1 \mathrm{U}$ of Taq DNA polymerase (Invitrogen) and ultrapure water q.s.p. to a final volume of $25 \mu \mathrm{L}$. The reactions were amplified in a My CyclerTM thermocycler (Biorad), with an initial denaturation of 5 minutes at $95^{\circ} \mathrm{C}$, followed by 35 denaturation cycles for 45 seconds at $95^{\circ} \mathrm{C}$, hybridization for 1 minute at $52^{\circ} \mathrm{C}$ and 1 minute and 30 seconds at $72^{\circ} \mathrm{C}$ extension and a final extension cycle at $72^{\circ} \mathrm{C}$ for 7 minutes.

Amplification products, stained with Gel Red (Biotium), were subjected to $1.0 \%$ agarose gel electrophoresis at $100 \mathrm{~V}$ for 90 min, visualized on ChemiDocTM XRS using ImageLabTM® software, and purified using Illustra ${ }^{\mathrm{TM}}$ ExoProstar $^{\mathrm{TM}}$ enzyme, following the manufacturer's instructions. Subsequently, sequencing was performed using an ABI-PRISM 3500 Genetic Analyzer (Life Technologies Corporation, USA).

\section{Results}

After referral for necropsy, two samples were collected from the sheep for histopathological and microbiological analysis. In the post-mortem examination, the presence of yellowish mucous material was observed in most of the bronchial tree, obliterating the bronchial lumen. The pleural surface contained random reddish multifocal areas ("marbled pattern"), affecting $60 \%$ of the organ, with consolidation and the presence of fibrin.

Histological changes were similar in both animals, with thickened alveolar septa, associated with moderate proliferation of pneumocytes and mononuclear interstitial infiltrate. In the bronchiolar and alveolar lumen, there was a variable neutrophil infiltration associated with fibrin aggregates and cellular debris, in addition to the occasional necrosis of the alveolar septa and the rare presence of syncytial cells, lymphocytes and plasma cells. Occasionally there were fibrin thrombi in the vascular lumen.

In the two lung samples, bacteria with phenotypic characteristics similar to $P$. stuartii were identified. The sequences obtained were compared and deposited into the GenBank database using the Basic Local Alignment Search Tool (BLAST) program (http://www.ncbi.nlm.nih.gov/blast/Blast.cgi) on the NCBI server (http: www.ncbi.nlm.nih.gov/BLAST) and the result demonstrated $100 \%$ identity with $P$. stuartii. The sequences were deposited at GenBank under the number MN733989.

\section{Discussion}

Respiratory diseases are common in domestic animals and theirs generate economic impacts related to productive loss, such as reduced weight gain and growth, drug costs and death (Azizi et al., 2013). Pneumonia in sheep can occur in lambs and adult animals depending on the existence of predisposing factors, it being considered a common disease (Azizi et al., 2013; Glendinning et al., 2017). Factors such as age, geographic location, environmental stressors, climate, nutritional 
status, immunosuppression, unhygienic conditions, managing system can contribute to the development of this disease (Azizi et al., 2013; Bell, 2008; Kalogianni et al., 2020). In sheep, the recent transport history can be considered a stress factor that predisposes to pneumonia (Brogden et al., 1998; Chakraborty et al., 2014; Scott, 2011). Reports of pneumonia in sheep caused by different etiologies have already been described in the literature (Azizi et al., 2013; Bell, 2008; Carmo et al., 2020; Cid et al., 2019; Jaÿ \& Tardy, 2019; Kalogianni et al., 2020), however there are no reports of P. stuartii.

The macroscopic and histological changes found in the lungs of the sheep were compatible with interstitial and fibrinopurulent bronchopneumonia (Ackermann \& Brogden, 2000). Sepsis in primates by P. stuartii, with the presence of fibrin and edema in the bronchi and bronchioles, has also been described by Liu et al. (2016). Histologically, there was intense neutrophil infiltration and exudation of fibrin in the alveoli, bronchi and bronchioles. Exudate is accompanied by necrosis and degenerate neutrophils (Hussain et al., 2017). These microscopic findings were present in the sheep, indicating fibrinopurulent bronchopneumonia. Tracheitis and acute suppurative bronchopneumonia have been reported in lambs associated with bacterial infections (Azizi et al., 2013; Hussain et al., 2017).

In the two lung samples, bacteria with phenotypic characteristics similar to P. stuartii (O'Hara et al., 2000) were isolated and their identity was confirmed molecularly (Ovchinnikova et al., 2013). The source of infection was not determined in these cases; however, it may have originated from the environment since it is found in soil, water and manure.

As an opportunistic pathogen in humans and animals, $P$. stuartii can be associated with primary and secondary infections (O'Hara et al., 2000). This microorganism has rarely been described in the veterinary literature, with no reports on the presence of this microorganism as a pathogen in respiratory tract infections of sheep to date.

\section{Conclusion}

Descriptions of respiratory diseases are common in farm animals, however, in sheep there is no pneumonia associated with $P$. stuartii. This etiological agent is an important public health pathogen that is associated with antibiotic resistance and it is widely distributed in the environment. There have been few studies on P. stuartii in animals, and this is the first report of the presence of this microorganism as a cause of interstitial and fibrinopurulent bronchopneumonia in sheep, confirmed by pathological findings, microbiological and molecular analyses. Therefore, it is suggested that epidemiological surveillance strategies should be carried out in animals to better understand their role in the dissemination of this pathogen.

\section{Acknowledgments}

We are grateful to the Coordination of Higher Education Personnel (Coordenação de Aperfeiçoamento de Pessoal de Nível Superior - CAPES) for the concession of a doctoral scholarship.

\section{References}

Ackermann, M. R., \& Brogden, K. A. (2000). Response of the ruminant respiratory tract to Mannheimia (Pasteurella) haemolytica. Microbes and Infection, 2(9), 1079-1088. doi:10.1016/S1286-4579(00)01262-4.

Almeida, F. S., Rigobelo, E. C., Marin, J. M., Maluta, R. P., \& Ávila, F. A. (2007). Diarréia suína: estudo da etiologia, virulência e resistência a antimicrobianos de agentes isolados em leitões na região de Ribeirão Preto-SP, Brasil. ARS Veterinaria, 23(3), 151-157. doi:10.15361/2175$0106.2007 \mathrm{v} 23 \mathrm{n} 3 \mathrm{p} 151-157$

Azizi, S., Korani, F. S., \& Oryan, A. (2013). Pneumonia in slaughtered sheep in south-western Iran: pathological characteristics and aerobic bacterial aetiology. Veterinaria Italiana, 49(1), 109-118. PMID: 23564592

Barbour, E. K., Hajj, Z. G., Hamadeh, S., Shaib, H. A., Farran, M. T., Araj, G., Faroon, O., Barbour, K. E., Jirjis, F., Azhar, E., Kumosani, T., \& Harakeh, S. (2012). Comparison of phenotypic and virulence genes characteristics in human and chicken isolates of Proteus mirabilis. Pathogens and global health, 106(6), 352-357. doi:10.1179/2047773212Y.0000000042 
Barl, P., Bedenic, B., Sardelic, S., Uzunovic, S., Vranes, J., \& Plecko, V. (2012). Spread of CTX-M-15 positive Providencia spp. causing urinary tract infections at the University Hospital Split in Croatia. Medicinski Glasnik (Zenica), 9(2), 317-324. PMID: 22926370

Bell, S. (2008). Respiratory disease in sheep: 1. Differential diagnosis and epidemiology. In Practice, 30(4), 200-207. doi:10.1136/inpract.30.4.200

Brogden, K. A., Lehmkuhl, H. D., \& Cutlip, R. C. (1998). Pasteurella haemolytica complicated respiratory infections in sheep and goats. Veterinary research, 29, 233-254. PMID: 9689740

Carmo, P., Uzal, F. A., Pedroso, P., \& Riet-Correa, F. (2020). Conidiobolomycosis, cryptococcosis, and aspergillosis in sheep and goats: a review. Journal of veterinary diagnostic investigation official publication of the American Association of Veterinary Laboratory Diagnosticians, Inc, 32(6), 826-834. doi:10.1177/1040638720958338

Chakraborty, S., Kumar, A., Tiwari, R., Rahal, A., Malik, Y., Dhama, K., Pal, A., \& Prasad, M. (2014). Advances in diagnosis of respiratory diseases of small ruminants. Veterinary Medicine International, 2014. doi:10.1155/2014/508304.

Chamberland, R. R., McElvania, T. E., Burnham, C. A., \& Kennedy, D. J. (2013). Renal abscess caused by a Providencia stuartii isolate biochemically misidentified as Pasteurella. Journal of clinical microbiology, 51 (8), 2775-2777. doi:10.1128/JCM.00937-13.

Cid, D., García-Alvarez, A., Domínguez, L., Fernández-Garayzábal, J.F., \& Vela, A.I. (2019). Pasteurella multocida isolates associated with ovine pneumonia are toxigenic. Veterinary microbiology, 232, 70-73. doi:10.1016/j.vetmic.2019.04.006

Crane, E. S., Shum, M., \& Chu, D. S. (2016). Case report: Providencia stuartii conjunctivitis. Journal of ophthalmic inflammation and infection, 6(1), 29. doi:10.1186/s12348-016-0097-9.

DI, H., Liang, S., Li, Q., Shi, L., Shima, A., Meng, H., Yan, H., \& Yamasaki, S. (2018). Providencia in retail meats from Guangzhou, China and Osaka, Japan: prevalence, antimicrobial resistance and characterization of classes 1, 2 and 3 integrons. The Journal of veterinary medical science, 80(5), 829-835. doi:10.1292/jvms.18-0037

Farmer, J. J., 3rd, Davis, B. R., Hickman-Brenner, F. W., McWhorter, A., Huntley-Carter, G. P., Asbury, M. A., Riddle, C., Wathen-Grady, H. G., Elias, C., \& Fanning, G. R. (1985). Biochemical identification of new species and biogroups of Enterobacteriaceae isolated from clinical specimens. Journal of clinical microbiology, 21(1), 46-76. doi:10.1128/jcm.21.1.46-76.1985

George, E. A., Kornik, R., \& Robinson-Bostom, L. (2020). Providencia stuartii septic vasculitis. JAAD case reports, 6(5), 422-425. doi:10.1016/j.jdcr.2020.02.043

Glendinning, L., Collie, D., Wright, S., Rutherford, K.M.D., \& McLachian, G.(2017). Comparing microbiotas in the upper aerodigestive and lower respiratory tracts of lambs. Microbiome, 145 (5), 2-9. doi:10.1186/s40168-017-0364-5.

Hussain, R., Mahmood, F., Ali, H. M., \& Siddique, A. B. (2017). Bacterial, PCR and clinico-pathological diagnosis of naturally occurring pneumonic pasturellosis (mannheimiosis) during subtropical climate in sheep. Microbial pathogenesis, 112, 176-181. doi:10.1016/j.micpath.2017.09.061

Iwata, S., Tada, T., Hishinuma, T., Tohya, M., Oshiro, S., Kuwahara-Arai, K., Ogawa, M., Shimojima, M., \& Kirikae, T. (2020). Emergence of CarbapenemResistant Providencia rettgeri and Providencia stuartii Producing IMP-Type Metallo- $\beta$-Lactamase in Japan. Antimicrobial agents and chemotherapy, 64(11), e00382-20. doi:10.1128/AAC.00382-20

Jaÿ, M., \& Tardy, F. (2019). Contagious Agalactia In Sheep And Goats: Current Perspectives. Veterinary medicine (Auckland, N.Z.), 10, 229-247. doi:10.2147/VMRR.S201847

Juneja, P., \& Lazzaro, B. P. (2009). Providencia sneebia sp. nov. and Providencia burhodogranariea sp. nov., isolated from wild Drosophila melanogaster. International journal of systematic and evolutionary microbiology, 59(Pt 5), 1108-1111. doi:10.1099/ijs.0.000117-0

Kalogianni, A.I., Bossis, I., Ekateriniadou, L.V., \& Gelasakis, A.I. (2020). Etiology, Epizootiology and Control of Maedi-Visna in Dairy Sheep: A Review. Animals : an open access journal from MDPI, 10(4), 616. doi:10.3390/ani10040616

Krake, P.R., \& Tandon, N. (2004). Infective endocarditis due to Providenca stuartii. Southern medical journal,97(10), 1022-1023. doi:10.1097/01.smj.0000141308.19657.ba

Ksentini, I., Gharsallah, H., Sahnoun, M., Schuster, C., Hamli Amri, S., Gargouri, R., Triki, M.A. Ksantini, M., \& Leclerque, A. (2019). Providencia entomophila sp. nov., a new bacterial species associated with major olive pests in Tunisia. PLoS ONE, 14 (10); e0223943. doi:10.1371/journal.pone.0223943.

Lane D.J. (1992). 16S/23S rRNA sequencing. In Stackebrandt E, Goodfellow M, editors. Nucleic acid techniques in bacterial systematics. New York: John Wiley \& Sons. 115-175.

Liakopoulos, A., Oikonomou, O., \& Wareham, D.W. (2017). Draft genome sequence of Providencia stuartii PS71, a multidrug-resistant strain associated with nosocomial infections in Greece. Genome Announc, 5(12): e00056-17. doi:10.1128/genomeA.00056-17.

Lin, K., Lin, A.N., Linn, S., Reddy, M., \& Bakshi, A. (2017). Recurrent primary suprahepatic abscess due to Providencia Stuartii: a rare phenomenon. Cureus, 9(9), e1691. doi:10.7759/cureus.1691.

Liu, D. X., Didier, P. J., Plauche, G., \& Pahar, B. (2016). Septicemia in an Indian Rhesus Macaque (Macaca mulatta) associated with Providencia stuartii. Journal of medical primatology, 45(6), 330-332. doi:10.1111/jmp.12230

Liu, J., Wang, R., \& Fang, M. (2020). Características clínicas e de resistência aos medicamentos das infecções por Providencia stuartii em 76 pacientes. The Journal of international medical research, 48 (10), 300060520962296. doi:10.1177/0300060520962296 
Research, Society and Development, v. 10, n. 16, e117101623295, 2021 (CC BY 4.0) | ISSN 2525-3409 | DOI: http://dx.doi.org/10.33448/rsd-v10i16.23295

Muller, H.E., O’Hara, C.M., Fanning, G.R., Hickman-Brenner, F.W., Swenson, J.M., \& Brenner, D.J. (1986). Providencia heimbachae, a new species of Enterobacteriaceae isolated from animals. International Journal of Systematic and Evolutionary Bacteriology, 36, 252-256. doi:10.1099/00207713-36-2-252.

O'Hara, C.M., Brenner, F.W., \& Miller, J.M. (2000). Classification, identification, and clinical significance of Proteus, Providencia and Morganella. Clinical Microbiology Reviews, 13(4), 534-546. doi:10.1128/cmr.13.4.534546.2000.

Ovchinnikova, O. G., Rozalski, A., Liu, B., \& Knirel, Y. A. (2013). O-antigens of bacteria of the genus Providencia: structure, serology, genetics, and biosynthesis. Biochemistry. Biokhimiia, 78(7), 798-817. doi:10.1134/S0006297913070110

Papadogiannakis, E., Perimeni, D., Velonakis, E., Kontos, V., \& Vatopoulos, A. (2007). Providencia stuartii infection in a dog with severe skin ulceration and cellulitis. The Journal of small animal practice, 48(6), 343-345. doi:10.1111/j.1748-5827.2006.00266.x

Quinn, P. J., Markey, B. K., Leonard, F.C., Hartigan, P., Fanning, S., \& Fitzpatrick E. S. (2011). Veterinary Microbiology and Microbial Disease. 2nd ed. Blackwell Science Ltd, Oxford. 1231p.

Sambrook, J., \& Russell D. W. (2004). Molecular Cloning: A Laboratory Manual $3^{\text {rd }}$ ed. Cold Spring Harbor Laboratory Press, New York, p.565 - 567.

Scott, P.R. (2011). Treatment and control of respiratory disease in sheep. The Veterinary clinics of North America. Food animal practice, 27(1), 175-186. doi:10.1016/j.cvfa.2010.10.016

Sipahi, O. R., Bardak-Ozcem, S., Ozgiray, E., Aydemir, S., Yurtseven, T., Yamazhan, T., Tasbakan, M., \& Ulusoy, S. (2010). Meningitis due to Providencia stuartii. Journal of clinical microbiology, 48(12), 4667-4668. doi:10.1128/JCM.01349-10

Somvanshi, V. S., Lang, E., Sträubler, B., Spröer, C., Schumann, P., Ganguly, S., Saxena, A. K., \& Stackebrandt, E. (2006). Providencia vermicola sp. nov., isolated from infective juveniles of the entomopathogenic nematode Steinernema thermophilum. International journal of systematic and evolutionary microbiology, 56(Pt 3), 629-633. doi:10.1099/ijs.0.63973-0

Tavares, C. P., Pereira, P. S., Marques, E., Faria, C., Jr, de Souza, M., de Almeida, R., Alves, C., Asensi, M. D., \& Carvalho-Assef, A. P. (2015). Molecular epidemiology of KPC-2-producing Enterobacteriaceae (non-Klebsiella pneumoniae) isolated from Brazil. Diagnostic microbiology and infectious disease, 82(4), 326-330. doi:10.1016/j.diagmicrobio.2015.04.002

Turner, S., Pryer, K. M., Miao, V. P., \& Palmer, J. D. (1999). Investigating deep phylogenetic relationships among cyanobacteria and plastids by small subunit rRNA sequence analysis. The Journal of eukaryotic microbiology, 46(4), 327-338. doi:10.1111/j.1550-7408.1999.tb04612.x

Wie S. H. (2015). Clinical significance of Providencia bacteremia or bacteriuria. The Korean journal of internal medicine, 30(2), 167-169. doi:10.3904/kjim.2015.30.2.167 